\title{
Clinical and microbiological characteristics of dogs in sepsis in an academic veterinary hospital in the north of Paraná ${ }^{1}$
}

\author{
Valdair E. Camargo Junior² (iD, Mônica V. Bahr Arias $^{2 *}$ (D) and Marcia R.E. Perugini (iD ${ }^{3}$
}

\begin{abstract}
Camargo Junior V.E., Bahr Arias M.V. \& Perugini M.R.E. 2020. Clinical and microbiological characteristics of dogs in sepsis in an academic veterinary hospital in the north of Paraná. Pesquisa Veterinária Brasileira 40(11):903-913. Departamento de Clínicas Veterinárias, Universidade Estadual de Londrina, Rodovia Celso Garcia Cid Km 380, Londrina, PR 86057-970, Brazil. E-mail: vicky@uel.br

Sepsis is a life-threatening organ dysfunction caused by a patient's unregulated response to an infectious process. In veterinary medicine, the exact incidence of sepsis is unknown. Early recognition of sepsis in critically ill patients is essential for rapid and effective therapeutic intervention. The present study aimed to apply the criteria of an adapted sepsis assessment protocol based on the Second International Consensus Definition for Sepsis and Septic Shock or Sepsis-2 of human medicine, in canine patients with suspected systemic inflammatory response syndrome (SIRS) and/or organ dysfunction, and to identify infectious agents as well as their antimicrobial resistance profile in the focus of infection, in the bloodstream and colonizing the rectal mucosa. Patients were evaluated for survival and severity of sepsis. Of the 37/42 dogs that met the sepsis criteria, six presented septic shock, $26(70.2 \%)$ had at least two signs of SIRS, and sepsis with organ dysfunction was diagnosed in 27 (73\%) dogs. The primary dysfunctions observed were decreased level of consciousness in 21/37 (56.8\%), hyperlactatemia in 19/37 (51.4\%), and hypoalbuminemia in 18/37 (48.6\%). Two or more SIRS signs associated with hypotension and hypoalbuminemia were related to more than half of the deaths. The most frequent infectious focus was skin and soft tissue in 20/37 (54\%), followed by organs and cavities in 8/37 (21.6\%). The survival rate was 56.7\%. Blood culture confirmed bacteremia in nine patients (24.3\%), with a predominance of Gram-positive microorganisms (Staphylococcus intermedius, Streptococcus spp.) in $66.6 \%$ of dogs and one yeast (Candida glabrata). The most frequent bacteria in the focus of infection were gram-negative bacteria (46.2\%), mainly Escherichia coli, Klebsiella pneumoniae, and Pseudomonas aeruginosa, in $19.5 \%, 14.6 \%$, and $12.1 \%$, respectively. We observed colonization by gram-negative bacteria such as E. coli-ESBL (31.5\%), K. pneumoniae-ESBL (15.7\%), and P. aeruginosa (15.7\%), and the presence of ESBL bacteria was more associated with death when compared with other microorganisms. Vancomycin-resistant Enterococcus (VRE) were isolated from rectal mucosa in four dogs. Gram-negative microorganisms were the most frequent in both infections and colonization, and most of them were resistant to fluoroquinolones, sulfonamides, tetracyclines, and cephalosporins. Based on this information, it can be concluded that mortality due to sepsis in dogs was high. Due to the presence of multi-resistant bacteria, the use of antimicrobials should be judicious, suggesting the implementation of the same precautions used in human hospitals to prevent the spread of multi-resistant microorganisms.
\end{abstract}

INDEX TERMS: Clinics, microbiology, sepsis, dogs, bacteria, blood culture, bacteremia, Brazil.

\footnotetext{
${ }^{1}$ Received on June 10, 2020.

Accepted for publication on August 10, 2020.

Part of Master's Thesis of the first author

${ }^{2}$ Departamento de Clínicas Veterinárias, Universidade Estadual de Londrina (UEL), Rodovia Celso Garcia Cid PR-445 Km 380, Londrina, PR 86051-990, Brazil. *Corresponding author: vicky@uel.br

${ }^{3}$ Laboratório de Microbiologia Clínica, Departamento de Patologia, Análises Clínicas e Toxicológicas, Centro de Ciências da Saúde, Universidade Estadual de Londrina (UEL), Rodovia Celso Garcia Cid PR-445 Km 380, Londrina, PR 86051-990, Brazil.
}

RESUMO.- [Características clínicas e microbiológicas de cães em sepse de um hospital veterinário escola do norte do Paraná.] A sepse é uma disfunção orgânica ameaçadora à vida, causada por uma resposta desregulada do hospedeiro à infecção e na medicina veterinária sua incidência exata é desconhecida. $\mathrm{O}$ reconhecimento precoce da sepse nos pacientes críticos é essencial para que a intervenção terapêutica seja rápida e eficaz. Assim, os objetivos do 
presente estudo foram aplicar os critérios de um protocolo de avaliação da sepse adaptado com base no Segundo Consenso Internacional para Sepse e Choque Séptico, ou Sepse-2, da medicina humana, em pacientes caninos com suspeita de infecção e/ou Síndrome da Resposta Inflamatória Sistêmica e/ou disfunção orgânica e identificar os agentes infecciosos bem como seu perfil de resistência a antimicrobianos no foco de infecção, na corrente sanguínea e colonizando a mucosa retal. Os pacientes foram avaliados quanto à sobrevivência e severidade da sepse. Dos 37/42 cães que se enquadraram nos critérios de sepse, seis estavam em choque séptico, 26 $(70,2 \%)$ apresentaram pelo menos dois sinais de SIRS, e a sepse com disfunção orgânica foi diagnosticada em 27 (73\%) cães. As principais disfunções verificadas foram diminuição do nível de consciência em $21 / 37$ (56,8\%), hiperlactatemia em 19/37 (51,4\%) e hipoalbuminemia em 18/37 (48,6\%). A presença de dois ou mais sinais de SIRS associados com hipotensão e hipoalbuminemia estiveram relacionadas com mais da metade dos óbitos. 0 foco infeccioso mais frequente foi pele e partes moles em 20/37 (54\%) seguido por órgãos e cavidades em 8/37 (21,6\%). A taxa de sobrevivência foi de $56,7 \%$. Na hemocultura confirmou-se bacteremia em nove pacientes $(24,3 \%)$, com predominância de microrganismos gram-positivos (Staphylococcus intermedius, Streptococcus spp.) em 66,6\% dos cães e uma levedura (Candida glabrata). As bactérias mais frequentes no foco de infecção foram as gram-negativas (46,2\%) principalmente Escherichia coli, Klebsiella pneumoniae e Pseudomonas aeruginosa, em 19,5\%, $14,6 \%$ e $12,1 \%$ respectivamente. Foi constatada colonização por bactérias gram-negativas como E. coli-ESBL (31,5\%), $K$. pneumoniae-ESBL $(15,7 \%)$ e $P$. aeruginosa $(15,7 \%)$, sendo que a colonização de cães por bactérias ESBL foi associada ao óbito quando comparada com outros microrganismos. Foram também isolados da mucosa retal Enterococcus resistentes à vancomicina (VRE) em quatro cães. Os microrganismos gram-negativos foram os mais frequentes, tanto nas infecções quanto nas colonizações e a maioria apresentava resistência à fluorquinolonas, sulfonamidas, tetraciclinas e cefalosporinas. Com base nestas informações, conclui-se que a mortalidade em decorrência da sepse em cães foi alta, e devido à presença de bactérias multirresistentes, o uso de antimicrobianos deve ser criterioso, sugerindo-se ainda a implantação das mesmas precauções utilizadas em hospitais humanos para evitar disseminação de microrganismos multirresistentes.

TERMOS DE INDEXAÇÃO: Clínica, microbiologia, sepse, cães, bactérias, hemocultura, bacteremia, caninos, Brasil.

\section{INTRODUCTION}

Sepsis is life-threatening organ dysfunction caused by a host's unregulated response to infection (Singer et al. 2016). Septic shock is a subset of sepsis. There are adjacent abnormalities of circulatory and cellular metabolism and persistent hyperlactatemia after adequate resuscitation with fluids. Vasopressor therapy is necessary to maintain mean arterial pressure (MAP) above $65 \mathrm{mmHg}$. In veterinary medicine, the exact incidence of sepsis is unknown, although dogs have been used as experimental models for human sepsis for many years (Otto \& Silverstein 2015). Veterinary mortality varies from 21 to 70\% (de Laforcade et al. 2003, Rabelo 2012, Hardy et al. 2018). The main etiologies of sepsis in this species include peritonitis of gastrointestinal or urogenital origin, pneumonia, immunosuppression (Otto \& Silverstein 2015), pyometra (Conti-Patara et al. 2012), necrotizing fasciitis (Troia et al. 2018) and wounds (de Laforcade et al. 2003, Bahr Arias et al. 2017). Gram-negative bacteria, members of the Enterobacteriaceae family, such as Escherichia coli, Klebsiella pneumoniae, Enterobacter spp., Pseudomonas spp. and Proteus spp., are primarily responsible for many of the severe infections in humans and animals (Otto \& Silverstein 2015). Gram-positive bacteria like Staphylococcus spp. and Streptococcus spp. also occur, albeit less frequently, in surgical site infections, pyoderma, otitis, urinary tract infection (Weese \& van Duijkeren 2010), and traumatic wounds (Bahr Arias et al. 2017).

Early recognition of sepsis in critically ill patients is essential for quick and effective therapeutic intervention (Otto 2007, Otto \& Silverstein 2015). In human medicine, since 1991, several consensuses have been reached to establish definitions regarding the diagnosis and treatment of sepsis. In 2001, the Sepsis-2 consensus was launched, containing a list of several signs of Systemic Inflammatory Response Syndrome (SIRS) in response to infection, which could be used to check whether the patient was septic (Levy et al. 2003). In 2004, the Surviving Sepsis Campaign's initial guidelines were launched, which were revised in 2008 and 2012. Several studies were incorporated into the manuscript, which in 2016 was called the Third International Consensus Definition for Sepsis and Septic Shock or Sepsis-3 (Singer et al. 2016, Rhodes et al. 2017). In this consensus, the concept of severe sepsis was removed, as well as the use of SIRS criteria for the diagnosis of sepsis (Singer etal. 2016, Castro \& Rabelo 2017), with problems in its acceptance by the medical community, mainly due to the possible occurrence of failure to identify septic patients (Carneiro et al. 2017).

There is no similar document in veterinary medicine, so several clinical and laboratory criteria help identify the infectious process and patients in sepsis (Castro \& Rabelo 2017, Troia et al. 2018). There is a lack of protocols and knowledge of prognostic indexes. There was no validation of the criteria proposed in the the Third International Consensus Definitions for Sepsis and Septic Shock (Sepsis-3), making its direct application impractical (Castro \& Rabelo 2017). The human consensus Sepsis-3 started to use the Sequential Organ Failure Assessment (SOFA) and Quick SOFA (in the first aid) scores to help diagnose sepsis. However, these have not been validated in veterinarians yet; the terms infection, sepsis, and septic shock are accepted (Castro \& Rabelo 2017). In most recent studies with dogs in sepsis, the parameters used for patient inclusion were the presence of two or more signs of SIRS and confirmation of infection by laboratory methods (Hardy et al. 2018, Troia et al. 2018, Letendre \& Goggs 2018).

This study aimed to use a protocol adapted for dogs, based on the Second International Consensus Definitions for Sepsis and Septic Shock (Sepsis-2), to identify sepsis patients and characterize their epidemiological, clinical, and laboratory profile concerning the clinical outcome in the "Hospital Veterinário Escola" of the North region of Paraná state, from 2016 to 2017.

\section{MATERIALS AND METHODS}

This study is observational, descriptive, and prospective with sampling for convenience, conducted in the sector of "Clínica Cirúrgica de Animais de Companhia" of the "Hospital Veterinário" of "Universidade Estadual 
de Londrina" (HV-UEL) from March 2016 to April 2017. Forty-two dogs with suspected sepsis were evaluated. The Animal Use Ethics Committee of the "Universidade Estadual de Londrina" (CEUA-UEL) approved this study, under process number 7274.2016.86.

Sepsis protocol. The protocol (Fig.1) was specially developed for this study based on the Second International Consensus Definition for Sepsis and Septic Shock or Sepsis-2 (Levy et al. 2003) adapted to the veterinary based on authors and articles published on the subject (Otto 2007, Rabelo 2012, ILAS 2015, Otto \& Silverstein 2015). The identification was carried out according to the following criteria. I) SIRS - animal with at least two of the following abnormal parameters: heart rate greater than 150 beats per minute; respiratory rate greater than 40 breaths per minute; temperature above $39.4^{\circ} \mathrm{C}$ or below $37.2^{\circ} \mathrm{C}$; leukocyte count above 19,000 or below $5,000 / \mathrm{mm}^{3}$ or left shift greater than $3 \%$. II) Sepsis - presence of a proven or suspected focus of infection associated with at least two more signs of SIRS; III) Sepsis with organ dysfunction - presence of sepsis associated or not with signs of SIRS with the presence of one of the following organic disorders: systolic pressure less than $90 \mathrm{mmHg}$ or mean arterial pressure less than 65 mmHg; oliguria; breathing difficulty; hyperlactatemia greater than $3.2 \mathrm{mmol} / \mathrm{dL}$; hypoalbuminemia less than $2.5 \mathrm{~g} / \mathrm{dL}$; decreased level of consciousness $(<17)$ according to an adapted Glasgow scale; creatinine greater than $2.0 \mathrm{mg} / \mathrm{dL}$; total bilirubin greater than $0.5 \mathrm{mg} / \mathrm{dL}$ and platelet count less than 50 thousand $/ \mathrm{mm}^{3}$ IV) Septic shock - presence of hypotension associated with sepsis not responsive to fluid resuscitation.

Specimen Collection. After identifying the septic patient, through the protocol mentioned above, blood was collected for blood culture from two different sites, material from the infectious focus and rectal swab. Blood cultures were duplicated to increase

\begin{tabular}{|c|c|c|}
\hline \multicolumn{2}{|c|}{$\begin{array}{l}\text { General Data } \\
\text { Name_} \\
\text { General Record___ Age__ } \\
\text { Gender__ } \\
\text { Breed__ }\end{array}$} & $\begin{array}{l}\text { Diagnosis and Treatment } \\
\text { epsis Vet }\end{array}$ \\
\hline \multicolumn{3}{|c|}{$\begin{array}{l}\text { Evaluation } 1 \\
\text { Patient presents } 2 \text { or more SIRS signs: Yes ( ) No ( ) } \\
\begin{array}{l}\text { ( ) Respiratory rate }>40 \mathrm{bpm} \text { ( ) Heart rate bpm }>150 \mathrm{bpm} \\
\text { () Hypothermia }<37.2^{\circ} \mathrm{C} \text {; or Hyperthermia }>39.4^{\circ} \mathrm{C} \\
\text { () Leukocytosis }>19.000 \text {, leukopenia }<5000 \text { or left shift }>3 \%\end{array}\end{array}$} \\
\hline \multicolumn{3}{|c|}{ 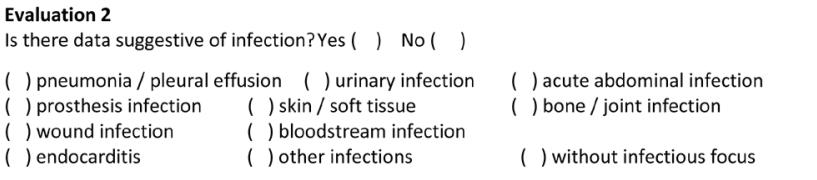 } \\
\hline \multicolumn{3}{|c|}{$\begin{array}{l}\text { Evaluation } 3 \\
\text { Is there at least one sign of organ dysfunction? Yes ( ) No( ) } \\
\text { ( ) systemic blood pressure }<90 \mathrm{mmHg} \text { or mean blood pressure }<60 \mathrm{mmHg} \\
\text { ( ) Creatinine }>2.0 \mathrm{mg} / \mathrm{dL} \text { ( ) Bilirubin }>0.5 \mathrm{mg} / \mathrm{dL} \text { ( ) platelet count }<50.000 \\
\text { ( ) lactate }>3.2 \mathrm{mmol} / \mathrm{dL} \text { ( ) decreased level of consciousness (Glasgow }<17 \text { ) } \\
\text { ( ) Albumin }<2.5 \mathrm{~g} / \mathrm{dL} \text { ( ) oliguria ( ) breathing difficulty ( ) no, only sepsis }\end{array}$} \\
\hline $\mathbf{F}$ & \multicolumn{2}{|r|}{ MEDICAL INTERVENTION } \\
\hline & ( ) collect material: & - Lactate ( ) Other cultures ( ) _ blood culture two samples ( ) \\
\hline & ( ) Antibiotic therapy & -Antibiotic \\
\hline & $\begin{array}{l}\text { ( ) prescribe crystalloid (10 } \\
\mathrm{mL} / \mathrm{kg} / 10 \mathrm{~min} \text { ) up to } 3 \text { times }\end{array}$ & - Fluid \\
\hline \multicolumn{3}{|r|}{ DIAGNOSIS } \\
\hline & ( ) sepsis & ( ) ruled out sepsis diagnosis \\
\hline
\end{tabular}

Fig.1. Protocol for the diagnosis of sepsis applied to dogs from the "Clínica Cirúrgica de Animais de Companhia" sector of the "Hospital Veterinário" of the "Universidade Estadual de Londrina" (HV-UEL) from March 2016 to April 2017. the test's sensitivity, which is considered positive only when there was growth in the two samples. The blood was collected with a syringe and needle after trichotomy and surgical antisepsis. In dogs weighing less than $10 \mathrm{~kg}$, between 1 and $3 \mathrm{ml}$ of blood were collected. In comparison, from dogs weighing more than $10 \mathrm{~kg}$ were collected between 3 and $5 \mathrm{~mL}$ of blood, which were inoculated into aerobic blood culture flasks at room temperature.

The sources of infection were selected according to the frequency and classified into pneumonia/pleural effusion, urinary tract infection, acute abdominal infection, skin/soft tissues (traumatic wounds), bone/joint infection, wound infection, bloodstream infection, endocarditis, prosthesis infection, with no defined focus or other infections (ILAS 2015)

When the material of the infectious focus for culture was a tissue fragment (example - wound), it was collected with a sterile scalpel and scissors and placed in a sterile flask containing sterile saline solution. When the material consisted of liquid or secretions, it was sent in the collection syringe itself to the laboratory.

Microbiological analysis. At the "Laboratório de Habilidades Farmacêuticas" of the "Centro de Ciências da Saúde" (CCS), commercial blood culture bottles (BD-Bactec ${ }^{\circledR}$ Peds PlusTM and BD Bactec ${ }^{\circledR}$ Plus) were placed in a BD BactecTM $9000^{\circledR}$ automated blood culture system (BD Diagnostics, Spars, MD, USA), which detects bacterial growth up to five days. For flasks that showed positive growth, an aliquot of the material was collected, which was sown on blood agar for later identification of the microbial agent, and analysis of sensitivity to antimicrobials.

Other collected materials were also inoculated in blood agar, chromogenic agar, and MacConkey agar and incubated at $37^{\circ} \mathrm{C}$. Afterward, the colonies that developed were identified according to Versalovic et al. (2011).

Rectal swab. The swabs were inoculated in two tubes containing Soy Broth Tripticaseína (Tryptic Soy Broth-TSB ${ }^{\circledR}$ ), one containing $8 \mu \mathrm{g} / \mathrm{ml}$ of cefotaxime and another containing $6 \mu \mathrm{g} / \mathrm{ml}$ of vancomycin. After overnight incubation at $37^{\circ} \mathrm{C}$, the broth from the first tube was peaked on a plate containing MacConkey ${ }^{\circledR}$ agar (Merck Sharp \& Dohme) supplemented with $8 \mu \mathrm{g} / \mathrm{mL}$ cefotaxime and the second on $\mathrm{VRE}^{\circledR}$ agar (OXOID) supplemented with $6 \mu \mathrm{g} / \mathrm{mL}$ vancomycin. After incubation for 24 hours, colonies that developed were identified using methodology standardized by Versalovic et al. (2011). Antimicrobial sensitivity was determined by disk diffusion according to the Clinical and Laboratory Standards Institute (CLSI 2008).

Antimicrobial sensitivity test (AST). The tests were performed using Muller Hinton agar. A bacterial concentration corresponding to 0.5 turbidity was used on the Mc Farland scale. Petri dishes and flasks containing paper discs impregnated with antibiotics were kept at room temperature for 20 to 30 minutes before use. The paper discs impregnated with antibiotics were selected based on the microbial agents identified in the samples, following the recommendations of CLSI (2008). They were added 15 minutes after sowing the organisms in the test. A maximum of five paper discs impregnated with antibiotics was used per $100 \mathrm{~mm}$ Petri dish, and they were incubated at $35-37^{\circ} \mathrm{C}$. The test was interpreted between 18 to 24 hours after incubation. The sensitivity profile was determined by measuring the growth inhibition zone, and the results were reported as sensitive, intermediate, or resistant.

Statistical analysis. Analysis of contingency tables ( $\chi 2$ test or Fisher's exact test) was used to verify the associations between categorical variables and clinical outcome of death or survival. Continuous variables were assessed using the Student's t-test. The Kolmogorov-Smirnov and Levene test was used to assess the 
normality of the distribution and the variances' homogeneity. Odds ratio (OR) and 95\% confidence interval (CI) were calculated. Categorical variables were expressed as absolute number (n), and percentage (\%) and continuous variables were expressed as mean \pm standard deviation. A binary logistic regression was performed using the Forward Stepwise selection method to outline the best predictors for the outcome of death. All analyzes were performed using IBM SPSS Statistics $24^{\circledR}$. The tests were bilateral with a 0.05 significance level.

\section{RESULTS}

After applying the adapted protocol to 42 patients in the period described, five animals had an infection, and 37 dogs met the sepsis classification criteria. Of these 37 dogs, 31 were in sepsis and six in septic shock. Table 1 shows the clinical and laboratory characteristics of the dogs in the study. Among the 37 dogs in sepsis, 51.4\% were females with an average weight of $13.8 \mathrm{~kg}$ (3-30 kg). Two or more signs of SIRS were

Table 1. Epidemiological, clinical and laboratory characteristics in relation to the total number of dogs treated with sepsis, to verify associations between variables and clinical outcome, in the "Clínica Cirúrgica de Animais de Companhia" sector at the “Hospital Veterinário” of the "Universidade Estadual de Londrina” (HV-UEL) from March 2016 to April 2017

\begin{tabular}{|c|c|c|c|c|c|}
\hline Variables & $\begin{array}{l}\text { Total dogs } \\
(n=37)\end{array}$ & $\begin{array}{c}\text { Discharge } \\
(n=21)\end{array}$ & $\begin{array}{l}\text { Death } \\
(n=16)\end{array}$ & p-value & OR (CI 95\%) \\
\hline \multicolumn{6}{|l|}{ Sex } \\
\hline Male & $18(48.6)$ & $11(52.4)$ & $7(43.8)$ & 0.603 & - \\
\hline Female & $19(51.4)$ & $10(47.6)$ & $9(56.3)$ & & \\
\hline \multicolumn{6}{|l|}{ Castration } \\
\hline Yes & $8(21.6)$ & $6(28.8)$ & $2(12.5)$ & 0.423 & - \\
\hline No & $29(78.4)$ & $15(71.4)$ & $14(87.5)$ & & \\
\hline Weight (kg) & $13.81( \pm 8.67)$ & $12.62( \pm 7.83)$ & $15.37( \pm 9.69)$ & 0.345 & - \\
\hline \multicolumn{6}{|l|}{ Clinical signs } \\
\hline Two or more SIRS signs & $26(70.2)$ & $13(61.9)$ & $13(81.3)$ & 0.285 & - \\
\hline Leukogram $\times 10^{3} ;<6>16 ;>3 \%$ & $27(72.9)$ & $14(66.7)$ & $13(86.7)$ & 0.252 & - \\
\hline Hypothermia $<37.2^{\circ} \mathrm{C}$; or Hyperthermia $>39.4$ & $20(54.0)$ & $10(47.6)$ & $10(62.5)$ & 0.368 & - \\
\hline Respiratory rate $>40 \mathrm{bpm}$ & $19(51.3)$ & $9(42.9)$ & $10(62.5)$ & 0.236 & - \\
\hline Heart rate bpm >150 bpm & $19(51.3)$ & $10(50.0)$ & $9(56.3)$ & 0.709 & - \\
\hline Respiratory difficulty & $8(21.6)$ & $1(4.8)$ & $7(43.8)$ & 0.007 & $\begin{array}{c}15.55 \\
(1.66-145.84)\end{array}$ \\
\hline \multicolumn{6}{|l|}{ Dysfunctions } \\
\hline Organic dysfunction & $27(73.0)$ & $12(57.1)$ & $15(93.8)$ & 0.023 & $\begin{array}{c}11.25 \\
(1.24-101.63)\end{array}$ \\
\hline Decreased level of consciousness & $21(56.8)$ & $9(42.9)$ & $12(75.0)$ & 0.093 & - \\
\hline Hyperlactatemia >3.2mmol/dL & $19(51.4)$ & $11(52.4)$ & $8(50.0)$ & 1.000 & - \\
\hline Hypoalbuminemia <2.5 g/dL & $18(48.6)$ & $7(33.3)$ & $11(68.8)$ & 0.049 & $\begin{array}{c}4.40 \\
(1.09-17.7)\end{array}$ \\
\hline Creatinine $>2.0 \mathrm{mg} / \mathrm{dL}$ & $9(24.0)$ & $4(19.0)$ & $5(31.3)$ & 0.458 & - \\
\hline Hypotension $(\mathrm{SP}<90 ; \mathrm{MBP}<65)$ & $9(24.3)$ & $1(4.8)$ & $8(50.0)$ & 0.002 & $\begin{array}{c}20.00 \\
(2.14-186.88)\end{array}$ \\
\hline Oliguria $0.5 \mathrm{ml} / \mathrm{kg} / \mathrm{hr}$ & $6(16.2)$ & $2(9.5)$ & $4(25.0)$ & 0.371 & - \\
\hline \multicolumn{6}{|l|}{ Diagnosis } \\
\hline Sepsis & $31(83.8)$ & $21(100)$ & $10(62.6)$ & & $\begin{array}{c}30.33 \\
(1.96-960.0)\end{array}$ \\
\hline Septic shock & $6(16.2)$ & $0(0.0)$ & $6(37.5)$ & 0.009 & $\begin{array}{c}25.32 \\
(1.28-499.0)\end{array}$ \\
\hline \multicolumn{6}{|l|}{ Infectious focus } \\
\hline Skin and soft tissue & $20(54.1)$ & $11(52.4)$ & $9(56.3)$ & 0.565 & - \\
\hline Acute abdominal infection & $9(24.3)$ & $4(19.1)$ & $5(31.3)$ & & \\
\hline Urinary tract & $5(13.5)$ & $4(19.0)$ & $1(6.3)$ & & \\
\hline Bloodstream & $2(5.4)$ & $1(4.8)$ & $1(6.3)$ & & \\
\hline Bone and joint & $1(2.7)$ & $1(4.8)$ & $1(6.3)$ & & \\
\hline \multicolumn{6}{|l|}{ Empirical antibiotic therapy } \\
\hline Enrofloxacin & $9(24.3)$ & $6(28.6)$ & $3(18.8)$ & 0.278 & - \\
\hline Enrofloxacin + Metronidazole & $6(16.2)$ & $3(14.3)$ & $3(18.8)$ & NA & \\
\hline Ampicillin + Gentamicin & $5(13.5)$ & $5(23.3)$ & $0(0.0)$ & & \\
\hline Ceftriaxone & $4(10.8)$ & $2(9.5)$ & $2(12.5)$ & & \\
\hline
\end{tabular}




\begin{tabular}{|c|c|c|c|c|c|}
\hline Variables & $\begin{array}{c}\text { Total dogs } \\
(\mathrm{n}=37)\end{array}$ & $\begin{array}{c}\text { Discharge } \\
(\mathrm{n}=21)\end{array}$ & $\begin{array}{c}\text { Death } \\
(\mathrm{n}=16)\end{array}$ & p-value & OR (CI 95\%) \\
\hline Enrofloxacin + Gentamicin & $3(8.1)$ & $1(4.8)$ & $2(12.5)$ & & \\
\hline Gentamicin & $3(8.1)$ & $1(4.8)$ & $2(12.5)$ & & \\
\hline Enrofloxacin + Ceftriaxone & $2(5.4)$ & $0(0.0)$ & $2(12.5)$ & & \\
\hline Gentamicin + Ceftriaxone & $1(2.7)$ & $1(4.8)$ & $0(0.0)$ & & \\
\hline Enrofloxacin + Doxycycline & $1(2.7)$ & $1(4.8)$ & $0(0.0)$ & & \\
\hline Cefazolin & $1(2.7)$ & $0(0.0)$ & $1(6.3)$ & & \\
\hline Amoxicillin/Clavulanate & $1(2.7)$ & $0(0.0)$ & $1(6.3)$ & & \\
\hline Sulfamethoxazole-Trimethoprim & $1(2.7)$ & $1(4.8)$ & $0(0.0)$ & & \\
\hline \multicolumn{6}{|l|}{ Cultures } \\
\hline Positive blood culture & $9(25)$ & $4(19.0)$ & $5(33.3)$ & 0.443 & - \\
\hline Positive infectious focus & $26(70.3)$ & $15(71.4)$ & $11(68.8)$ & 0.859 & - \\
\hline Positive rectal swab & $29(78.4)$ & $17(81.0)$ & $12(75.0)$ & 0.705 & - \\
\hline
\end{tabular}

found in $70.2 \%$ of cases. More than half had tachypnea and tachycardia (51.3\%). The presence of organic dysfunction was found in $73 \%$ of patients, decreased consciousness level in $56.8 \%$, and increased serum lactate in $51.4 \%$. The predominant infectious foci were skin and soft tissues (54.1\%), followed by acute abdominal and urinary tract infections. The empirical antimicrobials used at the first evaluation were enrofloxacin (24.3\%) and enrofloxacin in combination with metronidazole (16.2\%). Gram-negative bacteria predominated in $64 \%$ of cultures. The survival outcome was obtained in more than half of the dogs $(56.7 \%)$.

Table 2 shows the results of the microbiological analyzes. Bacterial growth occurred in 24.3\% (9/37) of blood cultures, with gram-positive microorganisms being the most frequent (66.6\%), mainly Staphylococcus pseudointermedius (33.3\%), Streptococcus canis (22.2\%), and Enterococcus spp. (11.1\%). In the blood culture of a dog, Candida glabrata was isolated. In infectious foci, Gram-negative bacteria such as Escherichia coli (19.5\%), Klebsiella pneumoniae (14.6\%), and Pseudomonas aeruginosa $(12.1 \%)$ were the most frequent, as well as in the rectal mucosa. However, in this location, several ESBL bacteria were identified. Enterococcus spp. resistant to vancomycin (VRE) in 10.5\% (4/38) and methicillin-resistant S. pseudointermedius (MRSP) in one case (Table 2).

Table 3 shows the general in vitro sensitivity profile of the isolated microorganisms. Aminoglycosides and amoxicillin/ clavulanate showed the lowest percentage of resistance. Ampicillin, sulfamethoxazole, and enrofloxacin were the antimicrobials with the highest resistance rates, reaching $90 \%, 89 \%$, and $87 \%$, respectively.

When the discharge/death outcome was interpreted by univariate analysis, dogs in septic shock were 29.33 times more likely to die than animals in sepsis $(\mathrm{p}=0.009)$. However, no difference was observed when the sepsis and sepsis with organ dysfunction were compared ( $\mathrm{p}=0.739$, OR: 1.5/0.135-16.55). The presence of respiratory difficulty ( $\mathrm{p}=0.007, \mathrm{OR}: 15.55)$, organ dysfunction ( $\mathrm{p}=0.023$, OR: 11.25 ), hypoalbuminemia ( $p=0.049$, OR: 4.40$)$ and hypotension ( $p=0.007$, OR: 20.0) were associated with death during hospitalization. The other variables were not associated with this outcome $(p>0.05)$ (Table 1).
Although the positivity of the infection focus cultures is not associated with the outcome, among the rectal swab isolates, ESBL bacteria's presence was associated with death compared to the $P$. aeruginos $a$ and Gram-positive isolates $(\mathrm{p}=0.039)$. The isolated Gram-negative bacilli (GNB), Gram-positive cocci (GPC), and polymicrobial samples obtained from cultures of the infectious focus did not differ in terms of the chance of death ( $p=0.789)$. It was impossible to analyze the isolates found in blood cultures with the outcome due to the small number of positive cultures ( $\mathrm{n}=9$ ) (Table 4).

Regarding the best predictors for death, after performing binary logistic regression with the forward stepwise input method, the discharge/death outcome was classified as a dependent variable. All clinical and laboratory variables were analyzed in the present study as explanatory variables (Table 5). The presence of two or more signs of SIRS ( $p=0.045$, OR: 8.78), hypotension ( $\mathrm{p}=0.013$, OR: 39.34), and hypoalbuminemia ( $p=0.014$, OR: 16.82) were independently associated with death. The present model correctly classified $82.4 \%$ of the cases, with a sensitivity of $90.0 \%$ and specificity of $71.4 \%$. In addition, the presence of two or more signs of SIRS together with hypotension and hypoalbuminemia explain $53.7 \%$ of the death outcome (Nagelkerke's $\mathrm{R}^{2}$ ). The other variables, such as sex, reproductive status, clinical signs, dysfunctions, diagnosis, infectious focus, treatment, presence of positive blood culture, culture of positive infectious focus, or positive rectal swab, were not independent predictors for death $(p>0.05)$.

\section{DISCUSSION}

In the prospective observational study described here, it was found that the application of a protocol allowed the identification of 37 dogs in sepsis, with six patients showing signs of septic shock. The primary dysfunctions observed were decreased level of consciousness, hyperlactatemia, and hypoalbuminemia. The presence of two or more SIRS signs associated with hypotension and hypoalbuminemia was related to more than half of the deaths. The most frequent infectious focus was skin and soft tissue, and gram-negative bacteria were mainly responsible for these conditions. Early recognition and intervention favored a survival rate in just over half of the patients. 
More than $70 \%$ of patients had at least two signs of SIRS associated with the infection, and approximately $30 \%$ showed no signs or expressed only one parameter. It demonstrates that the absence of these signs does not rule out sepsis since organic dysfunctions may be present in the septic patient even

Table 2. Frequency of microorganisms isolated from blood, infectious focus and rectal swab of 37 dogs characterized with sepsis

\begin{tabular}{|c|c|c|c|}
\hline Microorganism & Blood & $\begin{array}{l}\text { Infectious } \\
\text { focus }\end{array}$ & Rectal swab \\
\hline \multicolumn{4}{|l|}{ Enterobacteria } \\
\hline Escherichia coli & - & $8 / 41(19.5 \%)$ & $12 / 38(31.5 \%)^{* *}$ \\
\hline $\begin{array}{l}\text { Klebsiella } \\
\text { pneumoniae }\end{array}$ & $1 / 37(2.7 \%)$ & $6 / 41(14.6 \%)$ & $6 / 38(15.7 \%)^{* *}$ \\
\hline Enterobacter cloacae & - & $2 / 41(4.8 \%)$ & $3 / 38(7.8 \%)^{* *}$ \\
\hline Morganela spp. & - & - & $1 / 38(2.6 \%)^{* *}$ \\
\hline Proteus mirabilis & - & $3 / 41(7.3 \%)$ & $1 / 38(2.6 \%)^{* *}$ \\
\hline Citrobacter spp. & - & $1 / 41(2.4 \%)$ & $3 / 38(7.8 \%)^{* *}$ \\
\hline \multicolumn{4}{|l|}{ Gram-positive coccus } \\
\hline $\begin{array}{l}\text { Staphylococcus } \\
\text { intermedius (group) }\end{array}$ & $3 / 37(8.1 \%)^{\dagger+}$ & $4 / 41(9.7 \%)$ & - \\
\hline MRSP & - & - & $1 / 38(2.6 \%)$ \\
\hline Streptococcus sp. & $2 / 37(5.4 \%)^{\dagger+}$ & $2 / 41(4.8 \%)$ & - \\
\hline Enterococcus spp. & $1 / 37$ (2.7\%) & $4 / 41(9.7 \%)$ & $1 / 38(2.6 \%)$ \\
\hline VRE & & & $4(10.5 \%)$ \\
\hline CNE & - & $1 / 41(2.4 \%)$ & - \\
\hline Other GNB & - & - & - \\
\hline Acinetobacter sp. & - & $2 / 41(4.8 \%)$ & - \\
\hline Acromobacter sp. & - & $1 / 41(2.4 \%)$ & - \\
\hline $\begin{array}{l}\text { Pseudomonas } \\
\text { aeruginosa }\end{array}$ & - & $5 / 41(12.1 \%)$ & $6 / 38(15.7 \%)$ \\
\hline Stenotrophomonas sp. & - & $2 / 41(4.8 \%)$ & - \\
\hline Pasteurela multocida & $1 / 37(2.7 \%)^{\dagger}$ & - & - \\
\hline \multicolumn{4}{|c|}{ Fungi } \\
\hline Candida glabrata & $1 / 37(2.7 \%)$ & - & - \\
\hline TOTAL & $9 / 37(24.3 \%)$ & $41 *(100 \%)$ & $38 *(100 \%)$ \\
\hline
\end{tabular}

without signs of SIRS, as proposed by the Sepsis- 3 consensus (Rhodes et al. 2017). On the other hand, the SIRS criteria are predictive of exaggerated inflammation and would not necessarily indicate the presence of infection or an unregulated response (Castro \& Rabelo 2017). The diagnosis of sepsis performed only based on the list of organ dysfunctions, as proposed according to the human consensus Sepsis-3 may have limitations, since organic dysfunctions do not always result from an infectious process, thus causing a delay in the diagnosis and treatment of the infection (Castro \& Rabelo 2017). Thus, the balance between sensitivity of the SIRS criteria and specificity of organ dysfunctions in identifying canine sepsis patients can vary according to several factors, such as evaluated parameters, type, location, and extent of infection (Otto 2007).

The presence of two or more signs of SIRS, together with dysfunctions hypotension and hypoalbuminemia, represented the cause of more than half of deaths, portraying how organic dysfunctions worsen the prognosis, as they indicate greater severity of the condition. However, according to the Sepsis-3 Consensus these dysfunctions would no longer be classified as severe sepsis (Castro \& Rabelo 2017, Hardy et al. 2018). The focus of sepsis was traumatic wounds, but there was no relationship between this etiology and death. In humans, sepsis's

Table 3. General sensitivity profile of microorganisms isolated from dogs with sepsis seen at the "Clínica Cirúrgica de Animais de Companhia" of the "Hospital Veterinário" of the "Universidade Estadual de Londrina" (HV-UEL) from March 2016 to April 2017

\begin{tabular}{cc}
\hline Antimicrobial & \% resistant \\
\hline Amikacin & 15 \\
Amoxicillin/clavulanic acid & 15 \\
Ampicillin & 90 \\
Cefepime & 85 \\
Enrofloxacin & 87 \\
Gentamycin & 59 \\
Sulfamethoxazole & 89 \\
Tetracycline & 87 \\
Imipenem & 0
\end{tabular}

Table 4. Blood culture isolates, culture of the infectious focus and rectal swab and statistical analysis to verify associations between culture results and clinical outcome, in dogs treated with sepsis in the "Clínica Cirúrgica de Animais de Companhia" sector of the "Hospital Veterinário" of the "Universidade Estadual de Londrina" (HV-UEL) from March 2016 to April 2017

\begin{tabular}{|c|c|c|c|c|}
\hline Culture & Total dogs $\mathrm{n}$ and $\%$ & Discharge $\mathrm{n}$ and $\%$ & Death $\mathrm{n}$ and $\%$ & p-value \\
\hline \multicolumn{5}{|c|}{ Blood culture (positive) (n=9) } \\
\hline GPC & $6(66.6)$ & $2(50.0)$ & $4(80.0)$ & NA \\
\hline GNB & $2(22.6)$ & $1(25.0)$ & $1(20.0)$ & \\
\hline \multicolumn{5}{|c|}{ Infectious focus (positive) $(n=26)$} \\
\hline GNB & $4(15.4)$ & $2(13.3)$ & $2(18.2)$ & 0.789 \\
\hline \multicolumn{5}{|c|}{ Rectal swab (positive) (n=29) } \\
\hline ESBL & $21(72.4)$ & $9(53.0)$ & $12(100.0)$ & 0.039 \\
\hline Gram-positive & $4(13.8)$ & $4(23.5)$ & $0(0.0)$ & \\
\hline Pseudomonas aeruginosa & $4(13.8)$ & $4(23.5)$ & $0(0.0)$ & \\
\hline
\end{tabular}


Table 5. Binary logistic regression (Forward Stepwise) with the outcome discharge/death as a dependent variable and clinical and laboratory data as explanatory variables.

\begin{tabular}{lccccc}
\hline \multicolumn{1}{c}{ Explanatory variable } & B & Wald & DF & p-value & $\begin{array}{c}\text { OR } \\
\text { (CI 95\%) }\end{array}$ \\
\hline Two or more SIRS signals & 2.173 & 3.668 & 1 & 0.045 & $\begin{array}{c}8.78 \\
(1.95-18.14)\end{array}$ \\
Hypotension & 3.672 & 6.148 & 1 & 0.013 & $\begin{array}{c}39.34 \\
(2.16-71.70) \\
16.82\end{array}$ \\
Hypoalbuminemia & 2.823 & 6.316 & 1 & 0.014 & $\begin{array}{c}(1.86-25.04) \\
\text { DF = degree of freedom, OR = odds ratio, CI = confidence interval }\end{array}$
\end{tabular}

main etiologies are pneumonia, urinary tract infection, and intra-abdominal infections, with pneumonia being the most related to death (ILAS 2015). Respiratory infections were not observed in the present study; however, urinary, and intraabdominal infections were frequent and not related to death.

Although in The Third International Consensus Definitions for Sepsis and Septic Shock (Sepsis-3) held in 2016, the concept of severe sepsis was removed from the definitions due to the presence of life-threatening organ dysfunction since the beginning of the septic process, making the term "severe sepsis" redundant, this has not been validated in the veterinary medicine (Castro \& Rabelo 2017). The term severe sepsis was used in a recent article on sepsis that measured the procalcitonin biomarker in 53 dogs (Troia et al. 2018). There is controversy about accepting these terms in human medicine, as there is also disagreement about whether the Second or Third Consensus better identifies the critically ill patient (Carneiro et al. 2017). In addition, the Sequential Organ Failure Assessment (SOFA) and SOFA scores, from the Sepsis-3 Consensus, which allow the identification of critical patients, have not been validated in the veterinary. However, the terminology sepsis, septic shock, and sepsis are still used, considering that sepsis is an infection with a new organic dysfunction, as recommended by the "Instituto Latino Americano de Sepse” (Castro \& Rabelo 2017). Although 70\% of the animals were classified as having severe sepsis in the present study, survival was greater than the death rate. It demonstrates that despite the presence of organic dysfunction is associated with increased mortality, early recognition and treatment, through the application of the protocol developed to identify sepsis, allowed the identification of significant clinical and laboratory parameters associated with a greater chance of death. The parameters include the presence of two or more signs of SIRS, respiratory distress, hypotension, and hypoalbuminemia.

All dogs in the present study classified as being in septic shock died. Hypotension in sepsis is a consequence of decreased cardiac output due to the excess of inflammatory factors, causing other cardiovascular changes, common in both humans and animals in sepsis, with a low prognostic factor (Kumar et al. 2000). When hypotension does not respond to vasopressor treatment, patients are classified as in septic shock, and patients who met this classification had a worse outcome. In a study with bitches with pyometra, the presence of hypotension and septic shock were also related to a worse prognosis and death (Conti-Patara et al. 2012).

In assessing central nervous system dysfunction using the modified coma scale, it was possible to observe changes in the level of consciousness in more than half of the patients. Thus, it can be said that this neurological alteration is an important organ dysfunction to be considered in patients with sepsis, although it is not related to mortality. This alteration's pathophysiology is not yet fully understood. However, it is believed that decreased cerebral perfusion due to hypotension, hypovolemia, or arterial obstruction by microthrombi is involved (Johnson et al. 2004).

In the present study, just over half of the dogs showed an increase in lactate, showing impairment of tissue perfusion; however, this change was not correlated with mortality. In a study with bitches with pyometra and sepsis, diagnosed with at least two signs of SIRS and more than one sign of organ dysfunction, several tissue perfusion parameters were evaluated. It was concluded that the lactate concentration was also not a good mortality predictor when compared to the assessment of base deficit and central venous oxygen saturation, which discriminated better between survivors and non-survivors (Conti-Patara et al. 2012). One of the factors that may have contributed to the result was the number of cases, which was considered small, similar to the number of patients included in the present study. In a study with several veterinary centers, with a number of cases 14 times greater than that of the present study, lactate was a significant predictor of survival (Rabelo 2008). In human medicine, serum lactate levels have a better relationship with prognosis and assessment of response to treatment (Villar et al. 2019, Velissaris et al. 2019).

Patients with hypoalbuminemia at the time of inclusion in the study were more likely to die. One of the study's limitations was that the albumin value was not monitored after the dogs' inclusion in the study. However, all were in sepsis, and the majority had several organ dysfunctions. The progression of SIRS/Sepsis is characterized by rapid and unspecified clinical signs and serum concentration of acute-phase proteins. Septic patients have increased serum C-reactive protein (CRP), haptoglobin, ceruloplasmin, and fibrinogen in the blood. Other proteins, such as albumin and transferrin, gradually decrease during the inflammatory processes, being called negative proteins of the acute phase (Ceron et al. 2005). In a study of 33 dogs in SIRS, that was due or not to sepsis, hypoalbuminemia was observed, and the dogs that survived had higher values of total protein and albumin (Giunti et al. 2015). In another study, with 43 dogs with SIRS and sepsis, it was also observed that the gradual decrease in albumin values during hospitalization was related to a worse prognosis and that the plasma albumin concentration was inversely correlated with the severity of inflammation (Torrente et al. 2015). Albumin has several functions, such as maintaining oncotic pressure, transporting substances, mediating coagulation, inflammation, and healing, among others (Mazzaferro et al. 2002, Grimes et al. 2011). Although its measurement is cheap and easy to perform, it is considered a non-specific inflammatory biomarker. It can decrease in liver failure cases, enteropathies, nephrotic syndrome, malnutrition, and burns, among other conditions (Mazzaferro et al. 2002).

Acute kidney injury (AKI) in sepsis is multifactorial. It can result from hypovolemia, hypotension, and direct kidney injury. It is characterized by increased serum creatinine levels and decreased urinary output (Hoareau et al. 2014). In humans, 
AKI has been documented in $47 \%$ of patients with a clinical diagnosis of sepsis, being a public health concern. It affects not only survival but also worsens chronic kidney disease that many patients already have. In a study of dogs with sepsis due to abdominal disorders, AKI was seen in 12 to $16 \%$ of cases, and only $14 \%$ of affected dogs survived. The canine population's survival rate in general, with AKI, depends on the etiology and varies from 12 to $76 \%$. There are not many publications on kidney damage due to sepsis in veterinary medicine, as most articles focus on kidney damage due to nephrotoxins or renal ischemia (Keir \& Kellum 2015).

In the present study, both the frequency of the organic dysfunction and the mortality rate were high. The respiratory difficulty was the dysfunction with the highest association with death, as observed in a study in which survival was assessed concerning the presence of Multiple Organ Dysfunction Syndrome (MODS) in 114 dogs with sepsis (Kenney et al. 2010). In humans, the early identification of organ dysfunctions is essential to prevent MODS, as the mortality rate is affected by the severity of the underlying disease and the number of dysfunctional organs (Osterbur et al. 2014, Singer et al. 2016). The mortality rate in humans with MODS ranges from $20 \%$ to $100 \%$, and this value is affected by the number, severity, duration, type, and combination of compromised organ systems (Kenney et al. 2010, Osterbur et al. 2014). In veterinary medicine, although there are few studies on MODS (Osterbur et al. 2014, Hardy et al. 2018, Troia et al. 2018), the mortality rate of septic dogs has also increased in relation to the number of affected organs (Kenney et al. 2010).

Escherichia coli, Klebsiella pneumoniae, Pseudomonas aeruginosa, Staphylococcus intermedius, and Enterococcus spp. were the most commonly isolated bacteria from infectious foci, mainly in skin soft tissue infections. In most studies on dogs in SIRS/sepsis, the infectious agents observed were not discriminated, as the articles focused on biomarkers and prognostic factors (Kenney et al. 2010, Grimes et al. 2011, Conti-Patara et al. 2012, Giunti et al. 2015, Torrente et al. 2015, Walters et al. 2017, Hardy et al. 2018, Troia et al. 2018, Letendre \& Goggs 2018). In a study of dogs and cats with septic peritonitis, the most common bacteria in decreasing order were E. coli, Enterococcus spp., Staphylococcus spp. Enterobacter spp., Streptococcus spp., Proteus spp. and Klebsiella spp. In the same place where this study was carried out, in dogs with pyometra and SIRS, the bacteria most frequently isolated in two different periods were E. coli, Streptococcus spp., Klebsiella spp., Pseudomonas spp. and Staphylococcus spp. (Sant'Anna et al. 2014) and E. coli and Streptococcus spp. (Trautwein et al. 2017). In dogs with sepsis due to wounds, from 2012 to 2013, in the same place as the present study, the primary agents were P. aeruginosa, Streptococcus sp. and Enterococcus spp. Due to the significant problem of antimicrobial resistance in animals and humans, it is a consensus that the collection of material from the infection points for culture and antibiogram is carried out whenever possible to facilitate the early initiation of adequate treatment. Also, laboratories must use appropriate standards in examinations, such as those recommended by the Clinical and Laboratory Standards Institute (CLSI 2008) for the veterinary (Weese et al. 2015), as performed in the present study.

The choice of the antimicrobial used in septic patients was not related to death. However, in the cultures of the infectious foci, there was a high frequency of resistance to quinolones, ampicillin, sulfamethoxazole, and cefepime, a 4th generation cephalosporin. In the same place where this study was carried out, two studies were carried out evaluating the resistance of bacteria isolated from dogs with wounds (Arias et al. 2008) and dogs with wounds and sepsis (Bahr Arias et al. 2017). Another study evaluated the resistance of bacteria isolated from wounds, ear infections, and urinary system disorders in dogs and cats (Ishii et al. 2011). There was a trend of increasing resistance to antibiotics in the class of quinolones, aminoglycosides, and sulfonamides in the period between each study. It is worrisome because, in addition to the antibiotic options used in pets are decreasing, several genera of bacteria can be reservoirs of antibiotic resistance (Prescott 2014). E. coli, for example, is a commensal of humans and animals, widely disseminated in the environment. It has resistance genes that can be easily transferred to other pathogenic bacteria. The production of extended-spectrum beta-lactamases (ESBLs) and the development of resistance to quinolones are common in strains of E. coli and are a severe threat to humans and animals (Meireles et al. 2015). Still, concerning the comparison of antibiotic resistance indexes in the different periods, the amoxicillin/clavulanate association showed a critical reduction in resistance frequency. There was no change in the resistance to aminoglycosides and cephalosporins from the first to the fourth generation. However, the resistance to the latter remains high. Even though there is $100 \%$ sensitivity to carbapenem antimicrobials, their use should be restricted in the veterinary medicine to avoid the selection of multi-resistant bacteria that can be a risk to human health (Prescott 2014).

The collection and culture of material obtained from the rectal mucosa were performed in all dogs due to the importance of this monitoring in critically ill patients, since colonization by resistant bacteria can affect not only the result of the treatment but also the veterinary team and tutors of the animals, through the transmission of opportunistic bacteria (So et al. 2012, Hamilton et al. 2013). It is worrying that ESBL bacteria as well VRE have been isolated in the dogs in the present study. The presence of ESBL bacteria was more associated with death than P. aeruginosa and Gram-positive cocci. Simultaneously, in VREs it was not possible to correlate the presence of this bacterium with the outcome of death due to the small number of positive samples. Cases of ESBL enterobacterial infections were first reported in the late 1980s in humans. It is associated with increased mortality, length of stay, and costs (Razazi et al. 2012). There are already reports of infections caused by VRE bacteria (Abbott et al. 2009) in veterinary medicine. In a study in Korea, E. coli ESBL was identified in $33.3 \%$ of dogs admitted to Veterinary Hospitals (So et al. 2012).

According to the Surviving Sepsis Campaign (Rhodes et al. 2017), blood culture collection is indicated in all suspected sepsis cases. Bacteremia is a severe clinical complication with a critical role in the prognosis of sepsis. Positive blood cultures are found in approximately one-third of cases in human patients with severe sepsis (Hodgin \& Moss 2008). In Veterinary Medicine, information on the prevalence of bacteremia in dogs and cats is still scarce (Dow et al. 1989, Greiner et al. 2008, Tsuyuki et al. 2018), but it was estimated between 30-50\% (Calvert \& Thomason 2011). In this study, almost $25 \%$ of blood cultures were positive, of which more 
than half of the patients died. In a study of 100 critically ill dogs and cats, which 49 were in bacteremia, patients with severe disease and bacteremia were 15.6 times more likely to die than those with non-serious disease and negative blood culture results. However, Gram-negative bacteria results were the most frequent (Dow et al. 1989). In bitches with pyometra and sepsis, E. coli was the most common bacterium in blood culture (Kalenski et al. 2012). In the present study, Gram-positive bacteria were the leading cause of bloodstream infection as well as in a study with 140 dogs and 39 cats, in which Staphylococcus spp. and Streptococcus spp. were the main microorganisms (Greiner et al. 2008).

Candida glabrata was identified in a dog's blood culture that had been using quinolone for a long time and had diarrhea, abdominal effusion, presence of multi-resistant $E$. coli in peritoneal fluid, and candiduria. Candida spp. is a fungus that inhabits oral, gastrointestinal, upper respiratory, and urogenital mucosa of mammals, and several factors may be related to candidemia. These factors include prolonged hospitalization, use of antibiotics, alteration of the skin or mucous barriers due to trauma, surgery, catheter presence, urinary and vascular diseases, among others (Rogers et al. 2009). In this case, it cannot be said that the patient was in fungal sepsis, as not all inclusion criteria were met, such as the presence of two of the following three criteria: two positive blood cultures, detection of fungi at the tip of the catheter, severe septic clinical picture, and fungal septic metastases (Rogers et al. 2009). However, this fact is a warning since candidemia is already well known in human medicine in immunocompromised patients.

Sepsis is a clinical, multifactorial syndrome associated with several changes in physical and laboratory examination, and the absence of signs of a systemic inflammatory response does not rule out the possibility of dogs having sepsis. Due to the severity of the condition and lack of consensus on the diagnosis in veterinary medicine, there is great interest in the development of biomarkers and parameters to facilitate diagnosis and prognosis (de Laforcade et al. 2003, Conti-Patara et al. 2012, Giunti et al. 2015, Torrente et al. 2015, Hardy et al. 2018, Troia, et al. 2018). The protocol adapted based on the Second Human Consensus proved to be useful in identifying the septic patient, being essential the knowledge of the several parameters of identification of the sepsis phases so that it is recognized early, reducing costs and mortality. The collection of material for culture should be carried out, if possible, in all cases, to initiate the correct, fast, and effective treatment.

\section{CONCLUSIONS}

The results showed that the protocol adapted based on the Second International Consensus Definition for Sepsis and Septic Shock or Sepsis-2 used in the study allowed to verify the best parameters related to the early identification of the patient in sepsis and relate them to death. Most dogs showed two or more clinical signs of SIRS and/or changes in white blood cell count, temperature, respiratory rate, heart rate, and organ dysfunctions, including hypoalbuminemia, hypotension, and breathing difficulties. The best predictors for death were two or more SIRS parameters, hypotension, and hypoalbuminemia. Breathing difficulties and the presence of organ dysfunction were associated with mortality. ESBL bacteria colonizing the rectal mucosa also had a greater relationship with the death outcome.
The most frequent microorganisms found both as a cause of infection and colonizing the rectal mucosa were Gram-negative bacteria, E. coli, K. pneumoniae and P. aeruginosa. VRE, an important zoonotic agent, also colonized some patients, which is of great concern, suggesting that in Veterinary Medicine, the same precautions used in human ICUs should be implemented to prevent the spread of multi-resistant microorganisms. Blood culture was positive in approximately a quarter of the dogs and showed a prevalence of Gram-positive, including $S$. intermedius and Streptococcus spp. There was a high rate of antimicrobial resistance, mainly to quinolones, cephalosporins, ampicillin, and sulfonamides, emphasizing the need for the more careful use of antimicrobials. Aminoglycosides and amoxicillin/clavulanic acid still have the highest sensitivity rate.

Acknowledgements.- The authors are grateful to the "Conselho Nacional de Desenvolvimento Científico e Tecnológico" (CNPq) for the scholarship provided to Valdair E. Camargo Junior.

Conflict of interest statement.- The authors have no competing interests.

\section{REFERENCES}

Abbott Y., Kirby B.M., Karczmarczyk M., Markey B.K., Leonard F.C. \& Fitzgerald S. 2009. High-level gentamicin-resistant and vancomycin-resistant Enterococcus faecium isolated from a wound in a dog. J. Small Anim. Pract. 50(4):194-197.<https://dx.doi.org/10.1111/j.1748-5827.2008.00639.x> <PMid:19037894>

Arias M.V.B., Bataglia L.A., Aiello G., Carvalho T.T. \& Freitas J.C. 2008. Identificação da suscetibilidade antimicrobiana de bactérias isoladas de cães e gatos com feridas traumáticas contaminadas e infectadas. Semina, Ciênc. Agrárias 29(4):861-874.<https://dx.doi.org/10.5433/1679-0359.2008v29n4p861>

Bahr Arias M.V., Padilha F.N. \& Perugini M.R.E. 2017. Deep tissue culture and hemoculture in dogs with wounds and sepsis. Pesq. Vet. Bras. 37(12):14831490. <https://dx.doi.org/10.1590/s0100-736x2017001200020>

Calvert C.A. \& Thomason J.D. 2011. Cardiovascular infections, p.912-932. In: Greene C.E. (Ed.), Infectious Diseases of the Dog and Cat. 4th ed. Elsevier, St Louis. 1354p.

Carneiro A.H., Póvoa P. \& Gomes J.A. 2017. Dear Sepsis-3, we are sorry to say that we don't like you. Revta Bras. Ter. Intensiva 29(1):4-8. <https:// dx.doi.org/10.5935/0103-507x.20170002>

Castro B.G.A. \& Rabelo R.C. 2017. Sepsis-3: uma análise aplicada à medicina veterinária. Jornal Lavecc 9(3):1-13.

Ceron J.J., Eckersall P.D. \& Martýnez-Subiela S. 2005. Acute phase proteins in dogs and cats: current knowledge and future perspectives. Vet. Clin. Pathol. 34(2):85-99. <https://dx.doi.org/10.1111/j.1939-165x.2005. tb00019.x> <PMid:15902658>

CLSI 2008. Performance Standards for Antimicrobial Disk and Dilution Susceptibility Tests for Bacteria Isolated from Animals: Approved Standard. 3rd ed. Clinical and Laboratory Standards Institute, Wayne, Pennsylvania, 28(8):2-11.

Conti-Patara A., de Araújo Caldeira J., de Mattos-Junior E., de Carvalho H. da S., Reinoldes A., Pedron B.G., Patara M., Francisco Talib M.S., Faustino M., de Oliveira C.M. \& Cortopassi S.R.G. 2012. Changes in tissue perfusion parameters in dogs with severe sepsis/septic shock in response to goaldirected hemodynamic optimization at admission to ICU and the relation to outcome. J. Vet. Emerg. Crit. Care 22(4):409-418. <https://dx.doi. org/10.1111/j.1476-4431.2012.00769.X><PMid:22731982>

de Laforcade A.M., Freeman L.M., Shaw S.P., Brooks M.B., Rozanski E.A. \& Rush J.E. 2003. Hemostatic changes in dogs with naturally occurring sepsis. J.Vet. Intern. Med.17(5):674-679. <https://dx.doi.org/10.1111/j.1939-1676.2003. tb02499.x><PMid:14529134> 
Dow S.W., Curtis C.R., Jones R.L. \& Wingfield W.E. 1989. Bacterial culture of blood from critically ill dogs and cats: 100 cases (1985-1987). J. Am. Vet. Med. Assoc. 195(1):113-117. <PMid:2759883>

Giunti M., Troia R., Bergamini P.F. \& Dondi F. 2015. Prospective evaluation of the acute patient physiologic and laboratory evaluation score and an extended clinicopathological profile in dogs with systemic inflammatory response syndrome. J. Vet. Emerg. Crit. Care 25(2):226-233. <https:// dx.doi.org/10.1111/vec.12257><PMid:25427754>

Greiner M., Wolf G. \& Hartmann K. 2008. A retrospective study of the clinical presentation of 140 dogs and 39 cats with bacteraemia. J. Small Anim. Pract. 49(8):378-383. <https://dx.doi.org/10.1111/j.1748-5827.2008.00546.x> $<$ PMid:18422500>

Grimes J.A., Schmiedt C.W., Cornell K.K. \& Radlinksy M.A.G. 2011. Identification of risk factors for septic peritonitis and failure to survive following gastrointestinal surgery in dogs. J. Am. Vet. Med. Assoc. 238(4):486-494. <https://dx.doi.org/10.2460/javma.238.4.486><PMid:21320019>

Hamilton E., Kruger J.M., Schall W., Beal M., Manning S.D. \& Kaneene J.B. 2013. Acquisition and persistence of antimicrobial-resistant bacteria isolated from dogs and cats admitted to a veterinary teaching hospital. J. Am. Vet. Med. Assoc. 243(7):990-1000. <https://dx.doi.org/10.2460/ javma.243.7.990 > <PMid:24050566>

Hardy J.P., Streeter E.M. \& De Cook R.R. 2018. Retrospective evaluation of plasma cholesterol concentration in septic dogs and its association with morbidity and mortality: 51 cases (2005-2015). J. Vet. Emerg. Crit. Care 28(2):149-156. <https://dx.doi.org/10.1111/vec.12705><PMid:29489054>

Hoareau G.L., Epstein S.E., Palm C., Ybarra W., Jandrey K.E. \& Cowgill L.D. 2014. Resolution of anuric acute kidney injury in a dog with multiple organ dysfunction syndrome. J. Vet. Emerg. Crit. Care 24(6):724-730. <https:// dx.doi.org/10.1111/vec.12248> <PMid:25377656>

Hodgin K.E. \& Moss M. 2008. The epidemiology of sepsis. Curr. Pharm. Des. 14(19):1833-1839. <https://dx.doi.org/10.2174/138161208784980590> $<$ PMid:18691094>

ILAS 2015. Sepse: um problema de saúde pública. Instituto Latino Americano para Estudos da Sepse, Conselho Federal de Medicina, Brasília, 90p. Available at <https://www.ilas.org.br/assets/arquivos/ferramentas/livro-sepseum-problema-de-saude-publica-cfm-ilas.pdf> Accessed on June 2017.

Ishii J.B., Freitas J.C. \& Arias M.V.B. 2011. Resistência de bactérias isoladas de cães e gatos no Hospital Veterinário da Universidade Estadual de Londrina (2008-2009). Pesq. Vet. Bras. 31(6):533-537. <https://dx.doi. org/10.1590/S0100-736X2011000600013>

Johnson V., Gaynor A., Chan D.L \& Rozanski E. 2004. Multiple organ dysfunction syndrome in humans and dogs. J. Vet. Emerg. Crit. Care 14(4):158-166. <https://dx.doi.org/10.1111/j.1534-6935.2004.04016.x>

Kalenski T.A., Reinoldes A., Kitsis M., Faustino M., Talib M.S.F. \& Cortopassi S.R.G. 2012. Identification of the microorganisms involved in severe sepsis caused by pyometra in bitches undergoing ovariohysterectomy. Braz. J. Vet. Res. Anim. Sci. 49(2):130-138. <https://dx.doi.org/10.11606/issn.23183659.v49i2p130-138>

Keir I. \& Kellum J.A. 2015. Acute kidney injury in severe sepsis: pathophysiology, diagnosis, and treatment recommendations. J. Vet. Emerg. Crit. Care 25(2):200-209. <https://dx.doi.org/10.1111/vec.12297><PMid:25845505>

Kenney E.M., Rozanski E.A., Rush J.E., de Laforcade-Buress A.M., Berg J.R., Silverstein D.C., Montealegre C.D., Jutkowitz L.A., Adamantos S., Ovbey D.H., Boysen S.R. \& Shaw S.P. 2010. Association between outcome and organ system dysfunction in dogs with sepsis: 114 cases (2003-2007). J. Am. Vet. Med. Assoc. 236(1):83-87. <https://dx.doi.org/10.2460/javma.236.1.83> $<$ PMid:20043806>

Kumar A., Haery C. \& Parrillo J.E. 2000. Myocardial dysfunction in septic shock. Crit. Care Clin. 16(6):251-287. <https://dx.doi.org/10.1016/ s0749-0704(05)70110-x><PMid:10768082>
Letendre J.A. \& Goggs R. 2018. Determining prognosis in canine sepsis by bedside measurement of cell-free DNA and nucleosomes. J. Vet. Emerg. Crit. Care 28(6):503-511. <https://dx.doi.org/10.1111/vec.12773> <PMid:30299568>

Levy M.M., Fink M.P., Marshall J.C., Abraham E., Angus D., Cook D., Cohen J., Opal S.M., Vincent J-L. \& Ramsay G. 2003. 2001 SCCM/ESICM/ACCP/ATS/SIS International sepsis definitions conference. Int. Care Med. 29(4):530-538. <https://dx.doi.org/10.1007/s00134-003-1662-x> <PMid:12664219>

Mazzaferro E.M., Rudloff E. \& Kirby R. 2002. The role of albumin replacement in the critically ill veterinary patient. J. Vet. Emerg. Crit. Care 12(2):113-124. <https://dx.doi.org/10.1046/j.1435-6935.2002.00025.x>

Meireles D., Leite-Martins L., Bessa L.J., Cunha S., Fernandes R., de Matos A., Manaia C.M. \& Martins da Costa P. 2015. Molecular characterization of quinolone resistance mechanisms and extended-spectrum $\beta$-lactamase production in Escherichia coli isolated from dogs. Comp. Immunol. Microbiol. Infect. Dis. 41:43-48. <https://dx.doi.org/10.1016/j.cimid.2015.04.004>

Osterbur K., Mann F.A., Kuroki K. \& De Clue A. 2014. Multiple organ dysfunction syndrome in humans and animals. J. Vet. Intern. Med. 28(4):1141-1151. <https://dx.doi.org/10.1111/jvim.12364><PMid:24773159>

Otto C.M. \& Silverstein D.S. 2015. Sepsis, p.359-369. In: Greene C.E (Ed.), Infectious Diseases of the Dog and Cat. 4th ed. Elsevier, St Louis. 1383p.

Otto C.M. 2007. Sepsis in veterinary patients: what do we know and where can we go? J. Vet. Emerg. Crit. Care 17(4):329-332. <https://dx.doi. org/10.1111/j.1476-4431.2007.00253.x>

Prescott J.F. 2014. The resistance tsunami, antimicrobial stewardship, and the golden age of microbiology. Vet. Microbiol. 171(3/4):273-278. <https:// dx.doi.org/10.1016/j.vetmic.2014.02.035><PMid:24646601>

Rabelo R. 2012. Emergências de pequenos animais: condutas clínicas e cirúrgicas no paciente grave. Elsevier, Rio de Janeiro. 1184p.

Rabelo RC. 2008. Estudio y valor pronóstico de los parámetros relacionados con supervivencia en clínica de urgencias de pequeños animales: estudio multicéntrico. Master's Thesis, Universidad Complutense de Madrid, Madrid. 256p.

Razazi K., Derde L.P.G., Verachten M., Legrand P., Lesprit P. \& Brun-Buisson C. 2012. Clinical impact and risk factors for colonization with extendedspectrum $\beta$-lactamase-producing bacteria in the intensive care unit. Int. Care Med. 38(11):1769-1778. <https://dx.doi.org/10.1007/s00134-0122675-0> <PMid:22893223>

Rhodes A., Evans L.E., Alhazzani W., Levy M.M., Antonelli M., Ferrer R., Kumar A., Sevransky J.E., Sprung C.L., Nunnally M.E., Rochwerg B., Rubenfeld G.D., Angus D.C., Annane D., Beale R.J., Bellinghan G.J., Bernard G.R., Chiche J-D., Coopersmith C., De Backer D.P., French C.J., Fujishima S., Gerlach H., Hidalgo J.L., Hollenberg S.M., Jones A.E., Karnad D.R., Kleinpell R.M., Koh Y., Lisboa T.C., Machado F.R., Marini J.J., Marshall J.C., Mazuski .JE., McIntyre L.A., McLean A.S., Mehta S., Moreno R.P., Myburgh J., Navalesi P., Nishida O., Osborn T.M., Perner A., Plunkett C.M., Ranieri M., Schorr C.A., Seckel M.A., Seymour C.W., Shieh L., Shukri K.A., Simpson S.Q., Singer M., Thompson B.T., Townsend S.R., Van der Poll T., Vincent J-L., Wiersinga W.J., Zimmerman J.L. \& Dellinger R.P. 2017. Surviving sepsis campaign: international guidelines for management of sepsis and septic shock 2016. Int. Care Med. 43(3):304-377. <https://dx.doi.org/10.1007/s00134-0174683-6> <PMid:28101605>

Rogers C.L., Gibson C., Mitchell S.L., Keating J.H. \& Rozanski E.A. 2009. Disseminated candidiasis secondary to fungal and bacterial peritonitis in a young dog. J. Vet. Emerg. Crit. Care 19(2):193-198. <https://dx.doi. org/10.1111/j.1476-4431.2009.00405.x><PMid:19691571>

Sant'Anna M.C., Giordano L.G.P., Flaiban K.K.M.C., Muller E.E. \& Martins M.I.M. 2014. Prognostic markers of canine pyometra. Arq. Bras. Med. Vet. Zootec. 66(6):1711-1717. <https://dx.doi.org/10.1590/1678-6859>

Singer M., Deutschman C.S., Seymour C.W., Shankar-Hari M., Annane D., Bauer M., Bellomo R., Bernard G.R., Chiche J-D., Coopersmith C.M., Hotchkiss R.S., Levy M.M., Marshall J.C., Martin G.S., Opal S.M., Rubenfeld G.D., 
van der Poll T., Vincent J-L. \& Angus D.C. 2016. The third international consensus definitions for sepsis and septic shock (Sepsis-3). J. Am. Med. Assoc. 315(8):801-810. <https://dx.doi.org/10.1001/jama.2016.0287> <PMid:26903338>

So J.H., Kim J., Bae I.K., Jeong S.H., Kim S.H., Lim S., Park Y.H. \& Lee K. 2012. Dissemination of multidrug-resistant Escherichia coli in Korean veterinary hospitals. Diagn. Microbiol. Infect. Dis. 73(2):195-199. <https://dx.doi. org/10.1016/j.diagmicrobio.2012.03.010 > <PMid:22516765>

Torrente C., Manzanilla E.G., Bosch L., Fresno L., Rivera Del Alamo M., Andaluz A., Saco Y. \& Ruiz de Gopegui R.R. 2015. Plasma iron, C-reactive protein, albumin, and plasma fibrinogen concentrations in dogs with systemic inflammatory response syndrome. J. Vet. Emerg. Crit. Care 25(5):611-619. <https://dx.doi.org/10.1111/vec.12340> <PMid:26172578>

Trautwein L.G.C., Sant'Anna M.C., Justino R.C., Giordano L.G.P., Flaiban K.K.M. da C \& Martins M.I.M. 2017. Piometras em cadelas: relação entre o prognóstico clínico e o diagnóstico laboratorial. Ciênc. Anim. Bras. 18:1-10.<https:// dx.doi.org/10.1590/1089-6891v18e-44302>

Troia R., Giunti M. \& Goggs R. 2018. Plasma procalcitonin concentrations predict organ dysfunction and outcome in dogs with sepsis. BMC Vet. Res. 14(1):111. <https://dx.doi.org/10.1186/s12917-018-1427-y> $<$ PMid:29580242>

Tsuyuki Y., Kurita G., Murata Y. \& Takahashi T. 2018. Bacteria isolated from companion animals in Japan (2014-2016) by blood culture. J. Infect. Chemother. 24(7):583-587. <https://dx.doi.org/10.1016/j.jiac.2018.01.014> <PMid:29487032>
Velissaris D., Karamouzos V., Pantzaris N.D., Kyriakopoulou O., Gogos C. \& Karanikolas M. 2019. Relation between central venous, peripheral venous and arterial lactate levels in patients with sepsis in the emergency department. J. Clin. Med. Res.11(9):629-634. <https://dx.doi.org/10.14740/ jocmr3897><PMid:31523336>

Versalovic J., Carriol K., Funke G., Jorgensen J.H., Landry M. \& Warnock D.W. 2011. Manual of Clinical Microbiology. 10th ed. ASM Press. 2552p.

Villar J., Short J.H. \& Lighthall G. 2019. Lactate predicts both short- and long-term mortality in patients with and without sepsis. Infect Dis. 12:1-6. <https://dx.doi.org/10.1177/1178633719862776><PMid:31431799>

Walters A.M., O'Brien M.A., Selmic L.E. \& Mc Michael M.A. 2017. Comparison of clinical findings between dogs with suspected anaphylaxis and dogs with confirmed sepsis. J. Am. Vet. Med. Assoc. 251(6):681-688. <https://dx.doi.org/10.2460/javma.251.6.681> <PMid:28857707>

Weese J.S. \& van Duijkeren E. 2010. Methicillin-resistant Staphylococcus aureus and Staphylococcus pseudintermedius in veterinary medicine. Vet. Microbiol. 140(3/4):418-429. <https://dx.doi.org/10.1016/j.vetmic.2009.01.039> $<$ PMid:19246166>

Weese J.S., Giguère S., Guardabassi L., Morley P.S., Papich M., Ricciuto D.R. \& Sykes J.E. 2015. ACVIM consensus statement on therapeutic antimicrobial use in animals and antimicrobial resistance. J. Vet. Intern. Med. 29(2):487498. <https://dx.doi.org/10.1111/jvim.12562><PMid:25783842> 